\title{
ALTERNATIF SISTEM PENATAAN INFRASTRUKTUR KAWASAN PERMUKIMAN KUMUH DI KOTA PALANGKA RAYA
}

\author{
Muhing L. Agau ${ }^{1}$, Rusdi H.A. ${ }^{2}$, Candra Yuliana ${ }^{2}$ \\ ${ }^{1}$ Universitas Kristen Palangkaraya \\ ${ }^{2}$ Fakultas Teknik, Universitas Lambung Mangkurat
}

\begin{abstract}
ABSTRAK
Penataan Lingkungan adalah faktor penting dalam upaya perbaikan pemukiman. Sebagai indikator lingkungan yang bersih dan sehat bahwa kualitas peningkatan lingkungan yang berkelanjutan dapat diukur dengan ada atau tidaknya, dan infrastruktur yang baik atau buruk daerah perumahan tersebut. Pemukiman Palangka Permai terletak di antara jalan G. Obos dan Yos Sudarso Palangka Raya. Hal ini menunjukkan bahwa ada beberapa kelemahan dalam hal aspek kelayakan infrastruktur. Masalah dan tujuan yang ditetapkan dalam penelitian ini adalah untuk menentukan kondisi, penyebab dan sistem alternatif penataan infrastruktur kawasan perumahan yang dikelola oleh pengembang di kota Palangkaraya, sebagai dasar pembuatan alternatif pengaturan sistem infrastruktur untuk mencegah permukiman menjadi perkampungan kumuh di kota Palangkaraya. Hasil perhitungan skor untuk mengukur kelayakan kategori infrastruktur menunjukkan bahwa aspek lingkungan dan aspek lokasi biasa tidak dikategorikan. Aspek infrastruktur jalan, air dan drainase, fasilitas sosial, bangunan dan teknis pembuangan limbah cair dan padat memiliki kategori yang kurang layak. Sistem alternatif yang diusulkan infrastruktur permukiman adalah pada infrastruktur Jalan dengan mengoptimalkan cara lingkungan yang ada, membuat jalan baru, menyediakan lingkungan jalan yang saling berhubungan, pengadaan drainase di kedua sisi jalan dengan lebar dan tinggi> $10 \%$ dari lebar trotoar, mengoptimalkan ruang terbuka publik, ruang terbuka pribadi, pohon dan tata ruang hijau, lanskap dan area sabuk hijau sebagai fasilitas sosial, pengawasan dan tindakan terhadap perubahan penampilan bangunan, dengan mengevaluasi kepemilikan IMB dan membuat aturan khusus untuk mengatur fungsi bangunan, pengelolaan limbah padat (limbah) perlu membentuk organisasi untuk penanganan limbah. Untuk penanganan limbah cair adalah ketentuan lokal yaitu pembuangan sistem air limbah (on-site system) dengan sistem atau septic tank dan cubluk pembuangan terpusat (off site system) untuk membuat saluran tertutup untuk kombinasi air limbah dan air permukaan.
\end{abstract}

Kata kunci: infrastruktur, kawasan permukiman kumuh

\section{ABSTRACT}

The Environment Structuring is an important factor in settlement improvement efforts. As an indicator of a clean and healthy neighbourhoods that continuing environmental improvement quality can be measured by the presence or not, and good or poor infrastructure such residential areas. The settlement Palangka Permai is located between the street G. Obos and Yos Sudarso Palangka Raya. It indicates that there are some drawbacks in terms of infrastructure feasibility aspects.Problems and objectives set out in this study is to determine the condition, causes and alternative systems of infrastructure arrangement residential area which is managed by the developer in the Palangkaraya city, as a basis for making alternative arrangemen of the infrastructure systems to prevent neighborhoods from becoming a slum in Palangkaraya city.The results calculated scores to gauge the feasibility of infrastructure categories shows that the environmental aspect and location aspects of ordinary uncategorized. Aspects of road infrastructure, water and drainage, social facilities, buildings and technical of liquid and solid waste disposal has deserve less categories. The 
alternative system proposed settlement infrastructure is on Road infrastructure by optimizing the way the existing environment, create a new road exis, providing an environment of interconnected roads, procurement of drainage on either side of the road with a width and height of $\geq 10 \%$ from width of pavement, optimizing the public open space, private open space, trees and green layout, landscape and green belt areas as social facilities, oversight and action on changes in appearance of buildings, by evaluating the ownership of the IMB and to make special rules to regulate of the building function, waste solid management (waste) needs to form an organization for the handling of waste. For the liquid wastes handling is the local provision is to disposal waste water system (on-site system) with system or septic tank and cubluk disposal centralized (off site system) to create a closed channel to a combination of wastewater and surface water.

\section{Keywords: infrastructure, settlements region slum}

\section{PENDAHULUAN}

Perkembangan suatu daerah tidak lepas dari perkembangan jumlah penduduk yang terasa semakin meningkat dari tahun ke tahun, sehingga kebutuhan akan papan terutama rumah semakin meningkat pula. Sekarang ini perkembangan pembangunan akan infrastruktur perumahan permukiman juga semakin meningkat yang dibiayai oleh pihak pemerintah dan swasta.

Di Indonesia, jumlah penduduk merupakan ukuran besar kecilnya kota yang termasuk kota kecil adalah kota yang berpenduduk antara 5.000 sampai dengan 50.000 orang, kota sedang yaitu kota yang berpenduduk antara 50.000 sampai dengan 500.000 orang Sedangkan kota besar adalah kota yang berpenduduk 500.000 ke atas (Reksohadiprodjo, 2001: 6). Kota yang memiliki penduduk 1ebih dari satu juta disebut kota Metropolitan; yaitu suatu wilayah yang memiliki ciri sebagai suatu pusat perdagangan, industri, budaya dan pemerintahan yang dikelilingi oleh daerah semi urban (suburban), kawasan perumahan atau kota kota kecil yang digunakan sebagai tempat tinggal.

Kota Palangkaraya masih tergolong kota berkembang, tetapi dengan telah terhubungnya bangunan infrastruktur jalan dari beberapa daerah perkembangan kota terasa semakin padat terutama pada pusat kota. Perkembangan kota Palangkaraya tersebut ditandai dengan kebutuhan akan perumahan bagi masyarakat, sehingga pembangunan perumahan mengalami peningkatan yang sangat pesat. Setiap lahan-lahan yang kosong dan memiliki tingkat potensi yang memadai selalu diisi dengan perumahan dari berbagai jenis dan tipe. Adapun wilayah yang menjadi sasaran perkembangan pembangunan perumahan adalah di lokasi-lokasi strategis yang sebagian besar merupakan pusat keramaian seperti perekonomian, pendidikan dan sarana publik lainnya.

Lokasi yang menjadi obyek penelitian adalah kawasan perumahan dan pemukiman Palangka Permai yang terletak di antara jalan G. Obos dan Yos Sudarso Palangka Raya, dimana kawasan ini mulai dibangun pada tahun 1994, dan sekitar 15 tahun kemudian kawasan perumahan dan pemukiman tersebut berkembang sangat pesat karena ditunjang dengan beberapa fasilitas umum, khususnya sarana pendidikan, dimana sudah banyak dibangun sekolah dari SD, SLTP, SLTA bahkan perguruan tinggi STAIN. Luas wilayah perumahan dan pemukiman yang diindikasikan kumuh adalah seluas 225 ha atau sebesar $60 \%$ dari kawasan yang dibuat oleh pengembang seluas 375 ha.

Berdasarkan peninjauan secara langsung, dapat dilihat bahwa dari beberapa aspek teknis kawasan ini dapat dikatakan sudah mengarah pada kondisi yang tidak tertata dengan baik, sehingga menjadi kawasan kumuh. Pada kawasan ini ditemukan kenyataan bahwa hampir seluruh lingkungan perumahan dan pemukiman yang dibangun oleh pengembang telah berubah bentuk dan fungsinya, sehingga ruang terbuka hijau dimanfaatkan untuk menambah luas bangunan.

Hal ini ditambah lagi dengan semakin menyempitnya jalan yang digunakan. Kondisi tersebut memiliki tingkat kemungkinan yang sangat tinggi untuk ditetapkan sebagai daerah yang memiliki potensi kumuh di masa yang akan datang.

Penataan lingkungan merupakan faktor
sangat penting dalam usaha perbaikan
permukiman. Sebagus apapun perbaikan
permukiman tanpa memperhatikan penataan
lingkungan akan sia-sia. Sekalipun tempat tinggal,
jalan, penerangan dan lain-lain sudah memadai,


akan tetapi apabila faktor lingkungan diabaikan, maka permukiman akan terlihat kotor dan berkesan jorok bahkan yang sudah tertata rapi akan menjadi kumuh kembali. Selain itu lingkungan yang buruk menyebabkan timbulnya berbagai penyakit. Penataan lingkungan baik secara invidividuil seperti sistem sanitasi di rumah-rumah seperti: saluran pipa air bersih, mandi cuci kakus (MCK), maupun penataan lingkungan dalam skala yang lebih luas seperti penyediaan air bersih, saluran pematusan (drainase), pembuangan air limbah serta pembuangan sampah adalah sangat penting. Oleh karena itu salah satu indikator bersih dan sehatnya suatu lingkungan permukiman adalah peningkatan kualitas lingkungan yang berkesinambungan dan dapat diukur dengan ada atau tidak serta baik atau buruknya fasilitasfasilitas sanitasi dan infrastruktur tersebut di atas.

Sebagai fakta yang terjadi saat ini di Propinsi Bali pada pusat kota wisata yang sudah maju dan semakin padat penduduknya terutama pada daerah pantai Kuta. Penangan limbah padat maupun cair sudah menjadi suatu permasalahan yang sangat komplek, karena daerah tersebut sudah terkenal karena keindahan pantainya baik lokal maupun internasional. Untuk mengatasi permasalahan tersebut, (masalah limbah yang disebabkan oleh manusia) pemerintah mengeluarkan biaya yang tidak sedikit, karena pada daerah tersebut tidak tersedianya fasilitas infrastruktur penanganan limbah yang memadai, dan tidak tersedianya lahan untuk penanganan prasarana limbah akibat padatnya bangunan. Karena saluran drainase kiri kanan jalan yang berfungsi untuk mengalirkan air permukaan, berubah fungsi menjadi saluran limbah cair yang diakibatkan oleh manusia, baik itu dari hotel, rumah makan, toko-toko, rumah tangga dan lain sebagainya bercampur menjadi satu sehingga mengeluarkan bau yang tidak sedap dan mengakibatkan polusi udara di sekitar. Akibat dari hal tersebut, maka pemerintah akhirnya mengorbankan jalan dengan membangun saluran penaganan limbah manusia dengan membuat saluran di bawah jalan, dengan membongkar/menggali jalan yang sudah diaspal mulus di sepanjang jalan kota tersebut untuk mengatasi masalah limbah demi mempertahankan kawasan wisata yang sudah dikenal sampai mancanegara.

Pertumbuhan perumahan yang pesat di wilayah-wilayah sebagaimana yang telah disebutkan sebelumnya cenderung berubah fungsi tidak hanya sebagai tempat tinggal, tetapi lebih banyak dialihfungsikan sebagai tempat komersial seperti: toko, bengkel, kios-kios, rumah makan, barak maupun tempat kos-kosan. Hal itu sudah barang tentu menjadikan lingkungan tempat tinggal bukan berfungsi sebagaimana mestinya, tetapi lebih diarahkan kepada kegiatan yang bersifat komersil dan tidak menjamin kenyamanan, kebersihan dan kelayakan untuk lingkungan pemukiman yang baik.

Bertitik tolak permasalahan tersebut di atas penulis akan mengangkat topik tentang, "Alternatif Sistem Penataan Infrastruktur Kawasan Pemukiman Kumuh di Kota Palangkaraya". Ditinjau dari jaminan keamanan, kenyamanan, kebersihan, keindahan maupun kesehatannya sesuai kemampuan daya beli masyarakat.

Berdasarkan uraian yang telah disajikan pada latar belakang, maka rumusan permasalahan yang diambil dalam penelitian ini adalah bagaimana alternatif sistem penataan infrastruktur kawasan perumahan kumuh?

\section{KAJIAN TEORI}

\section{Alternatif Penataan Infrastruktur (Perumahan /Pemukiman)}

Infrastruktur yang terbagi menjadi bermacam-macam sub-sistem itu mengakibatkan sistem infrastruktur menjadi kompleks. Tahapan mulai dari studi, perencanaan, pembangunan dan pemanfaatan sekaligus pemeliharaan merupakan proses yang perlu dilakukan untuk membuat sistem infrastruktur yang terpadu dan menyeluruh serta berkelanjutan. Sistem infrastruktur juga merupakan proses dengan keterlibatan berbagai aspek, interdisiplin dan multi sektoral. Salah satu tantangan utama dalam perencanaan sistem infrastruktur adalah mempertimbangkan bagaimana semua itu dapat memberikan pengaruh pada lainnya, keterkaitan satu sama lain dan dampak-dampaknya (Grigg, dalam Robert, 2005: 103).

Infrastruktur perumahan dan pemukiman saling bergantung dan terkait, secara lebih spesifik dapat digambarkan sebagaimana Gambar 1 berikut: 


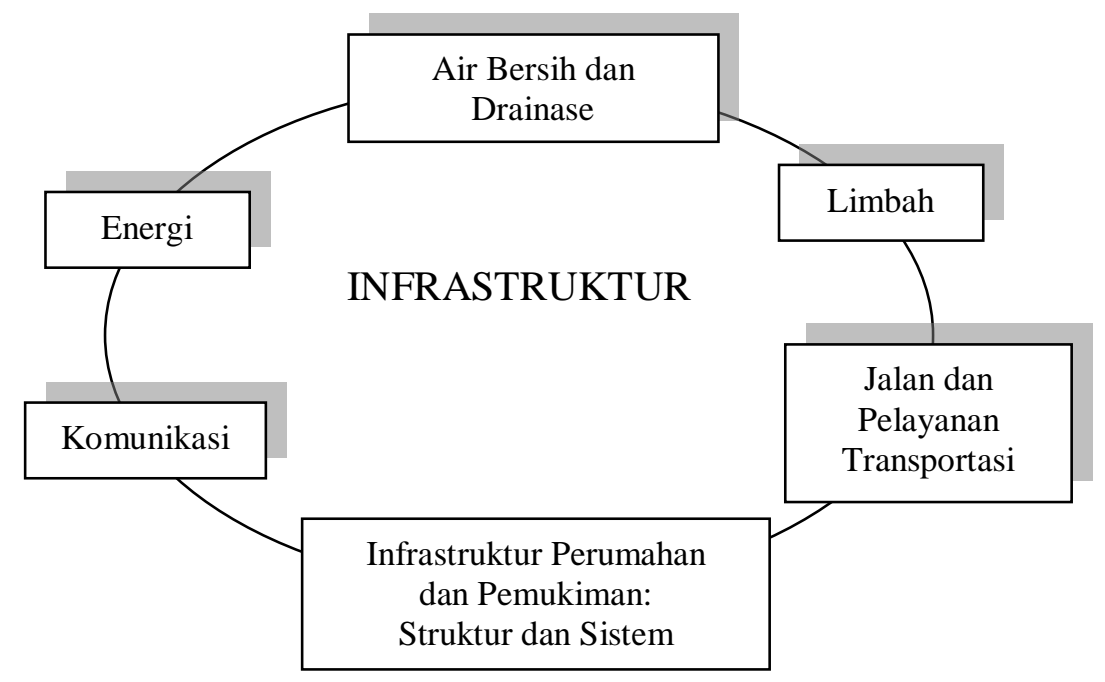

Gambar 1. Hubungan infrastruktur dengan Perumahan dan Pemukiman

Menurut Albertson dalam Robert (2005: 105) solusi untuk infrastruktur yang ideal adalah sangat sulit untuk menuntaskan semua persoalan infrastruktur (keseimbangan antara kebutuhan dan kelestarian lingkungan). Kesulitan ini disamping akibat tindakan manusia, juga dari alam itu sendiri. Pengelolaan sistem infrastruktur yang berkelanjutan dan berwawasan lingkungan mempunyai beberapa dimensi yang harus diintegrasikan ke semua aspek pembangunannya, yang antara lain adalah sebagai berikut.

1. Environmental sustainability: perlindungan lingkungan yang berkelanjutan untuk generasi mendatang.

2. Economic sustainability: setiap pengembangan variabel secara ekonomi.

3. Socio-cultural sustainability: setiap inovasi harus harmoni antara pengetahuan lokal dan budaya, praktek, pengetahuan (sains) dan teknologi tepat guna.

4. Political sustainability: link birokrasi (pemerintahan) dan masyarakat. Para pemimpin formal dan informal untuk semua sektor tertentu dalam masyarakat lokal harus mampu menjalin komunikasi dengan strukturstruktur politik dan birokrasi. Missing link terjadi karena tidak adanya perantara (interface).

5. Teknologi tepat guna

Untuk pembangunan infrastruktur perlu dicari materi-materi yang berhubungan langsung maupun tidak langsung terhadap kegiatan pembangunan tersebut. Materi-materi itu antara lain meliputi profil kondisi fisik dasar, Sumber
Daya Manusia (SDM), sarana prasarana yang telah ada, Sumber Daya Alam (SDA), sosial budaya, ekonomi, pola pemanfaatan ruang serta arahan pengembangan wilayah. Untuk lebih memperjelas materi-materi tersebut berikut ini uraiannya (yang terbatas dan memungkinkan munculnya komponen lainnya):

1. Profil kondisi fisik dasar, meliputi: topografi, geografis, hidrologi, klimatologi dan lain-lain.

2. Profil sumber daya manusia/kependudukan, meliputi: jumlah dan struktur penduduk, laju pertumbuhan, kepadatan penduduk, lapangan kerja, tingkat pendidikan dan lain-lain.

3. Profil sosial budaya, meliputi: karakteristik sosial penduduk karakteristik budaya (adat) masyarakat, kehidupan sosial masyarakat, dan lain-lain.

4. Profil sarana prasarana meliputi semua infrastruktur yang ada.

5. Profil sumber daya alam, meliputi: potensi alam, kelemahan dari kondisi alam yang ada (weakness), peluang pengembangan alam yang ada, daya dukung alam (lahan), dan lain-lain.

6. Profil perekonomian, meliputi: potensi kegiatan sektoral (skala lokal), potensi produksi tanaman pangan, sektor perindustrian, potensi sentra industri kecil dan hortikultura, dan lain-lain.

7. Pemanfaatan ruang, meliputi: pola penggunaan tanah, pola pengembangan tata guna lahan, dan pola perubahan tata guna lahan.

8. Arahan pengembangan kota, meliputi: fungsi dan peranan kota, struktur tata ruang kota, dan lain-lain. 


\section{METODE PENELITIAN}

\section{Lokasi dan Objek Penelitian}

Penelitian ini dilakukan pada kawasan lingkungan perumahan permukiman yang dibangun oleh pengembang (devloper) sebelum ditempati oleh pemilik dan yang sudah ditempati oleh masyarakat/ pemilik $\geq 15$ tahun di kota Palangkaraya, dimana penulis akan memberikan gambaran dari topik dan fenomena yang terjadi pada obyek penelitian, khususnya mengenai alternatif sistem penataan infrastruktur kawasan mencegah terjadinya pemukiman kumuh di kota Palangkaraya.

\section{Teknik Pengumpulan Data}

\section{Data Primer}

Data penelitian ini didapat dengan menggunakan beberapa metode, dimana data primer didapat dengan melakukan:

1. Wawancara dengan penghuni untuk mendapatkan informasi-informasi secara langsung mengenai kondisi tempat tinggal dan lingkungan yang mereka tempati saat ini.

2. Survey dan dokumentasi yang dilakukan dengan melakukan pengumpulan data/perekaman data dari obyek penelitin, penghuni dan instansi-instansi terkait khususnya pemerintah kota Palangkaraya.

\section{Data Sekunder}

Data sekunder berasal dari buku literatur, internet dan data dari instansi-instansi terkait antara lain : Badan Perencanaan Pembangunan Daerah (Bappeda), Dinas Pekerjaan Umum (PU), Badan Pertanahan Nasional (BPN), Kantor Badan Pusat Statistik (BPS) kota Palangkaraya, Kantor Kecamatan, Kantor Kelurahan, Real Estate Indonesia (REI), Perumnas.

\section{Pembuatan Sistem Penataan Baru}

Data primer dan sekunder dianalisis secara deskriptif, dengan membandingkan fenomena, permasalahan dan kondisi infrastruktur yang ada, khususnya hubungan infrastruktur kawasan perumahan dan permukiman kumuh. Berdasarkan hal tersebut kemudian dibuat suatu alternatif pemecahan masalah karena infrastruktur terdiri dari bermacam-macam sub-sistem yang kompleks. Tahapan mulai dari studi, perencanaan, pembangunan dan pemanfaatan sekaligus pemeliharaan merupakan proses yang perlu dilakukan untuk membuat sistem infrastruktur yang terpadu dan menyeluruh serta berkelanjutan.

Pembuatan sistem penataan infrastruktur yang baru, dalam penelitian ini adalah ditinjau dari kriteria pemukiman yang memenuhi syarat berdasarkan Peraturan Menteri Pekerjaan Umum Nomor 54/PRT/1991 tentang Pedoman Teknis Pembangunan Perumahan Sangat Sederhana, dengan memperhatikan sistem infrastruktur yang terpadu, menyeluruh dan berkelanjutan, yang antara lain adalah:

1. Energi, dimana fasilitas infrastruktur ini adalah untuk memenuhi kebutuhan listrik dan penerangan bagi penghuni perumahan dan pemukiman. Fasilitas energi tersebut dapat diwujudkan dengan tersedianya tempat untuk mendirikan tiang listrik di bahu jalan.

2. Komunikasi, dimana fasilitas infrastruktur ini dipergunakan untuk seseorang melakukan hubungan dengan orang lain melalui telepon. Fasilitas komunikasi yang dimaksud dalam perumahan dan pemukiman adalah tersedianya tempat untuk mendirikan tiang telepon di bahu jalan.

3. Air bersih dan drainase, dimana fasilitas infrastruktur ini adalah untuk memenuhi kebutuhan air bersih. Sedangkan drainase adalah untuk pembuangan air permukaan (hujan) yang dipertimbangkan secara teknis sehingga lingkungan terbebas dari genangan air.

4. Limbah, dimana fasilitas infrastruktur ini adalah untuk menangani pembuangan benda cair maupun padat yang kotor, yang disebabkan oleh manusia di lingkungan tersebut.

5. Jalan dan pelayanan transportasi, yang merupakan fasilitas infrastruktur untuk mendukung aktivitas sosial untuk datang dan pergi dari dan ke lingkungan tersebut.

Berdasarkan sistem infrastruktur yang terpadu, menyeluruh dan berkelanjutan di atas, maka dibuat suatu tahapan proses penelitian yang diharapkan dapat menjadi alternatif pembahasan untuk penataan infrastruktur kawasan perumahan dan pemukiman yang layak dan berwawasan lingkungan. Adapun tahapan proses penelitian 


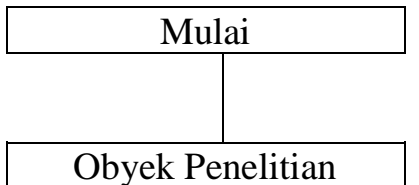

Masalah Sistem Penataan Infrastruktur Kawasan Pemukiman Kumuh di Kota Palangkaraya

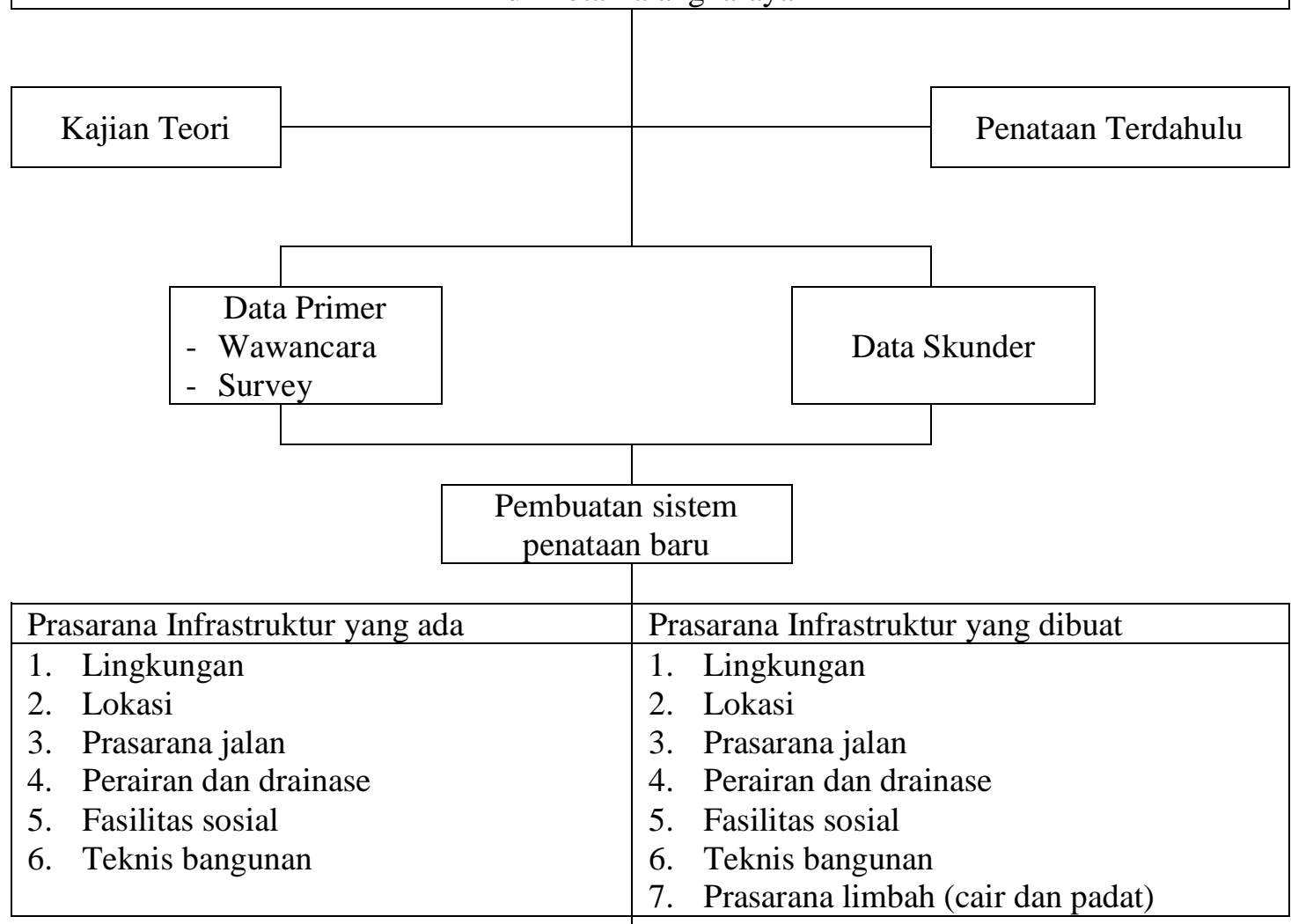

\begin{tabular}{|c|}
\hline $\begin{array}{c}\text { Alternatif Sistem Penataan } \\
\text { Infrastruktur yang baru }\end{array}$ \\
\hline Selesai \\
\hline
\end{tabular}

Gambar 2. Bagan Alur Penelitian

\section{HASIL PENELITIAN}

\section{Pengolahan Data Variabel Penelitian}

Total skor kemudian dibagi dalam kelas-kelas kategori berdasarkan interval, maka disusun pembagian kelas kategori seperti terlihat pada Tabel 1 berikut.
Tabel 1. Kategori Kelayakan Infrastruktur Berdasarkan Skor Responden

\begin{tabular}{|c|l|c|c|c|c|c|c|}
\hline \multirow{2}{*}{ No. } & \multirow{2}{*}{$\begin{array}{c}\text { Aspek } \\
\text { Infrastruktur }\end{array}$} & \multicolumn{4}{|c|}{ Tingkat Kelayakan } & \multirow{2}{*}{ Jlh } \\
\cline { 3 - 8 } & SL & L & B & KL & TL & \\
\hline 1 & Lingkungan & - & 50 & - & 25 & - & 75 \\
\hline 2 & Lokasi & - & - & - & 60 & 15 & 75 \\
\hline 3 & Prasarana & - & - & 10 & 58 & 6 & 75 \\
\hline
\end{tabular}




\begin{tabular}{|c|c|c|c|c|c|c|c|}
\hline \multirow{2}{*}{ No. } & \multirow{2}{*}{$\begin{array}{c}\text { Aspek } \\
\text { Infrastruktur }\end{array}$} & \multicolumn{5}{|c|}{ Tingkat Kelayakan } & \multirow{2}{*}{ Jlh } \\
\hline & & SL & $\mathbf{L}$ & $\mathbf{B}$ & KL & TL & \\
\hline & jalan & & & & & & \\
\hline 4 & $\begin{array}{l}\text { Perairan dan } \\
\text { drainase }\end{array}$ & - & - & 13 & 59 & 3 & 75 \\
\hline 5 & $\begin{array}{l}\text { Fasilitas } \\
\text { sosial }\end{array}$ & - & - & 38 & 36 & 1 & 75 \\
\hline 6 & $\begin{array}{l}\text { Teknis } \\
\text { bangunan }\end{array}$ & - & 2 & 24 & 46 & 3 & 75 \\
\hline 7 & $\begin{array}{l}\text { Pembuangan } \\
\text { limbah cair } \\
\text { dan padat }\end{array}$ & - & 1 & 12 & 43 & 19 & 75 \\
\hline & TOTAL & - & 53 & 97 & 327 & 47 & 524 \\
\hline
\end{tabular}

Sumber : Hasil Analisis

Keterangan :

$\begin{array}{ll}\text { SL } & \text { : Sangat Layak } \\ \text { L } & \text { : Layak } \\ \text { B } & : \text { Biasa } \\ \text { KL } & : \text { Kurang Layak } \\ \text { TL } & : \text { Tidak Layak }\end{array}$

Berdasarkan hasil analisis dan pengklasifikasian kategori kelayakan infrastruktur dari hasil jawaban responden terhadap kuisioner yang dibagikan, dihasilkan tingkat prosentase kelayakan sebagai berikut :

\section{Lingkungan}

Total pendapat responden yang menyatakan bahwa aspek lingkungan memiliki kategori layak adalah sebanyak 50 orang $(66,67 \%)$ dan memiliki kategori kurang layak adalah sebanyak 25 orang $(33,33 \%)$.

2. Lokasi

Total pendapat responden yang menyatakan bahwa aspek lokasi memiliki kategori kurang layak adalah sebanyak 60 orang $(80,00 \%)$ dan memiliki kategori tidak layak adalah sebanyak 15 orang $(20,00 \%)$.

3. Prasarana jalan

Total pendapat responden yang menyatakan bahwa aspek prasarana jalan memiliki kategori biasa adalah sebanyak 10 orang $(13,33 \%)$, memiliki kategori kurang layak adalah sebanyak 58 orang $(77,33 \%)$, dan memiliki kategori tidak layak adalah sebanyak 6 orang $(8,00 \%)$.

4. Perairan dan drainase

Total pendapat responden yang menyatakan bahwa aspek perairan dan drainase memiliki kategori biasa adalah sebanyak 13 orang $(17,33 \%)$, memiliki kategori kurang layak adalah sebanyak 59 orang $(78,67 \%)$, dan memiliki kategori tidak layak adalah sebanyak 3 orang $(4,00 \%)$.

5. Fasilitas sosial

Total pendapat responden yang menyatakan bahwa aspek fasilitas sosial memiliki kategori biasa adalah sebanyak 38 orang (50,67\%), memiliki kategori kurang layak adalah sebanyak 36 orang $(48,00 \%)$, dan memiliki kategori tidak layak adalah sebanyak 1 orang $(1,33 \%)$.

6. Teknis bangunan

Total pendapat responden yang menyatakan bahwa aspek teknis bangunan memiliki kategori layak adalah sebanyak 2 orang (2,67\%), memiliki kategori biasa adalah sebanyak 24 orang $(32,00 \%)$, memiliki kategori kurang layak adalah sebanyak 46 orang $(61,33 \%)$, dan memiliki kategori tidak layak adalah sebanyak 3 orang $(4,00 \%)$.

7. Pembuangan limbah cair dan padat

Total pendapat responden yang menyatakan bahwa aspek teknis bangunan memiliki kategori layak adalah sebanyak 1 orang (1,33\%), memiliki kategori biasa adalah sebanyak 12 orang $(16,00 \%)$, memiliki kategori kurang layak adalah sebanyak 43 orang $(57,33 \%)$, dan memiliki kategori tidak layak adalah sebanyak 19 orang $(25,33 \%)$.

Untuk lebih jelasnya dapat dilihat pada format perhitungan persentase skala interval kelas yang merupakan kategori kelayakan, yaitu sebagai berikut.

1. Jumlah soal sebanyak 20 butir, dengan pilihan skor jawaban maksimal adalah 5, sehingga skor maksimal adalah 20 × $5=100$. Sedangkan pilihan skor jawaban minimal adalah 1, sehingga skor minimal adalah $20 \times 1=20$

2. Interval kelas adalah jumlah kategori kelayakan yang dikemukakan dalam penelitian adalah 5 kategori, yaitu: sangat layak, layak, biasa, kurang layak dan tidak layak.

3. Hasil perhitungan kelas interval ditetapkan berdasarkan satuan persen, dimana kalkulasi besarnya skor maksimal dikurangkan dengan skor minimal yang kemudian dibagi dengan kelas kategori kelayakan akan didapatkan hasil pembagian persentase pada masing-masing kelas kategori kelayakan, sebagaimana terlihat pada tabel 2 . 
Alternatif Sistem Penataan Infrastruktur ..., Muhing L. Agau ${ }^{(1)}$, Rusdi H.A. ${ }^{(2)}$, Candra Yuliana ${ }^{(3)}$

Tabel 2. Kategori Kelayakan Infrastruktur Berdasarkan Persentase

\begin{tabular}{|c|c|c|}
\hline NO. & $\begin{array}{c}\text { KATEGORI } \\
\text { KELAYAKAN }\end{array}$ & PERSENTASE \\
\hline 1 & Sangat Layak & $83,1 \%-$ \\
& & $100 \%$ \\
\hline 2 & Layak & $67,1 \%-$ \\
& & $83 \%$ \\
\hline 3 & Biasa & $51,1 \%-$ \\
& & $67 \%$ \\
\hline 4 & Kurang Layak & $35,1 \%-$ \\
& & $51 \%$ \\
\hline
\end{tabular}

\begin{tabular}{|c|c|c|}
\hline NO. & KATEGORI & PERSENTASE \\
\hline 5 & KELAYAKAN & \\
\hline & Tidak Layak & $20 \%-$ \\
& $35 \%$ \\
\hline
\end{tabular}

Sumber : Hasil Analisis

Berdasarkan hasil perhitungan total skor maksimal dan total skor minimal, kemudian diperhitungkan persentase total skor hasil jawaban responden, yang kemudian dimasukkan ke dalam kategori kelayakan infrastruktur sebagaimana terlihat pada Tabel 3 berikut

Tabel 3. Kategori Kelayakan Aspek Infrastruktur

\begin{tabular}{|c|l|c|c|c|c|}
\hline No. & \multicolumn{1}{|c|}{ Aspek Infrastruktur } & $\begin{array}{c}\text { Skor } \\
\text { Maksimal }\end{array}$ & $\begin{array}{c}\text { Skor } \\
\text { Total }\end{array}$ & $\begin{array}{c}\text { Persen } \\
(\boldsymbol{\%})\end{array}$ & $\begin{array}{c}\text { Kategori } \\
\text { Kelayakan }\end{array}$ \\
\hline 1 & Lingkungan & 750 & 432 & 57,60 & B \\
\hline 2 & Lokasi & 2250 & 1166 & 51,82 & B \\
\hline 3 & Prasarana jalan & 750 & 328 & 42,73 & KL \\
\hline 4 & Perairan dan drainase & 1500 & 706 & 47,07 & KL \\
\hline 5 & Fasilitas sosial & 375 & 187 & 49,87 & KL \\
\hline 6 & Teknis bangunan & 1125 & 534 & 47,47 & KL \\
\hline 7 & $\begin{array}{l}\text { Pembuangan limbah cair dan } \\
\text { padat }\end{array}$ & 750 & 303 & 40,40 & KL \\
\hline
\end{tabular}

Sumber : Hasil Analisis

Keterangan :

$\begin{array}{ll}\text { SL } & \text { : Sangat Layak } \\ \text { L } & \text { : Layak } \\ \text { B } & : \text { Biasa } \\ \text { KL } & : \text { Kurang Layak } \\ \text { TL } & \text { : Tidak Layak }\end{array}$

Untuk lebih jelasnya mengenai kategori kelayakan dari aspek-aspek infrastruktur yang diteliti, dapat dilihat pada uraian berikut.

1. Aspek Lingkungan, memiliki total skor maksimal sebesar 750, dan skor total hasil jawaban responden sebesar 432, sehingga persentase hasil jawaban tersebut adalah sebesar $57,60 \%$. Nilai persentase tersebut menunjukkan bahwa aspek lingkungan dapat dimasukkan ke dalam kategori Biasa.

2. Lokasi, memiliki total skor maksimal sebesar 2250, dan skor total hasil jawaban responden sebesar 1166, sehingga persentase hasil jawaban tersebut adalah sebesar $51,82 \%$. Nilai persentase tersebut menunjukkan bahwa aspek lokasi dapat dimasukkan ke dalam kategori Biasa.

3. Prasarana jalan, memiliki total skor maksimal sebesar 750, dan skor total hasil jawaban responden sebesar 328, sehingga persentase hasil jawaban tersebut adalah sebesar $42,73 \%$. Nilai persentase tersebut menunjukkan bahwa aspek prasarana jalan dapat dimasukkan ke dalam kategori Kurang Layak.

4. Perairan dan drainase, memiliki total skor maksimal sebesar 1500, dan skor total hasil jawaban responden sebesar 706, sehingga persentase hasil jawaban tersebut adalah sebesar $47,07 \%$. Nilai persentase tersebut menunjukkan bahwa aspek perairan dan drainase dapat dimasukkan ke dalam kategori Kurang Layak.

5. Fasilitas sosial, memiliki total skor maksimal sebesar 375, dan skor total hasil jawaban responden sebesar 187, sehingga persentase hasil jawaban tersebut adalah sebesar 49,87\%. Nilai persentase tersebut menunjukkan bahwa aspek fasilitas sosial dapat dimasukkan ke dalam kategori Kurang Layak.

6. Teknis bangunan, memiliki total skor maksimal sebesar 1125, dan skor total hasil jawaban responden sebesar 534, sehingga persentase hasil jawaban tersebut adalah sebesar 47,47\%. Nilai persentase tersebut menunjukkan bahwa aspek fasilitas sosial dapat dimasukkan ke dalam kategori Kurang Layak.

7. Pembuangan limbah cair dan padat, memiliki total skor maksimal sebesar 750 , dan skor total 
hasil jawaban responden sebesar 303, sehingga persentase hasil jawaban tersebut adalah sebesar 40,40\%. Nilai persentase tersebut menunjukkan bahwa aspek pembuangan limbah cair dan padat dapat dimasukkan ke dalam kategori Kurang Layak.

\section{Sistem Penataan Infrastruktur Kawasan Pemukiman Kumuh Di Kota Palangkaraya}

\section{Aspek Penyebab Terbentuknya Infrastruktur Kumuh}

Pesatnya pembangunan kota Palangkaraya maka kebutuhan rumah makin meningkat, dengan mengalihkan fungsi kepemilikan lahan awal yang dimiliki masyarakat ke tangan pengembang perumahan (developer) agar masyarakat dapat memiliki dengan harga terjangkau dengan mengakses Kredit Pemilikan Rumah (KPR) Pengembang cenderung merubah ukuran lahan menjadi antara lain : $(10 \times 14 \mathrm{~m}, 9 \times 15 \mathrm{~m}$ dll), asal dapat memenuhi luas minimal sesuai peraturan yang berlaku untuk Rumah Sangat Seserhana (RSS) dan Rumah Sederhana (RS). Perubahan tersebut dilakukan karena pengembang mengacu pada Undang-Undang No. 4 Tahun 1992 Tentang Perumahan dan Permukiman serta (Peraturan Menteri Pekerjaan Umum No.54/PRT/1991 tentang Pedoman Teknik Pembangunan Perumahan Sangat Sederhana). Secara spesifik perubahan luas lahan kavlingan tampak pada Gambar 3 berikut

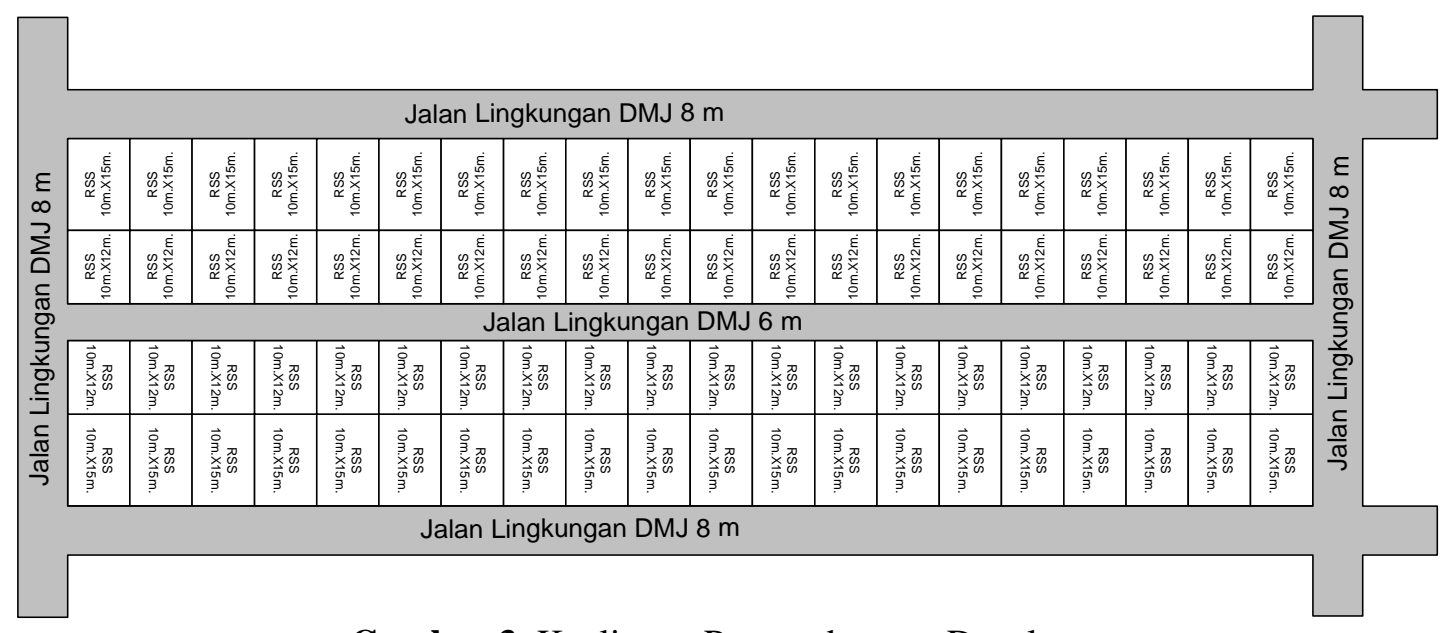

Gambar 3. Kavlingan Pengembangan Developer

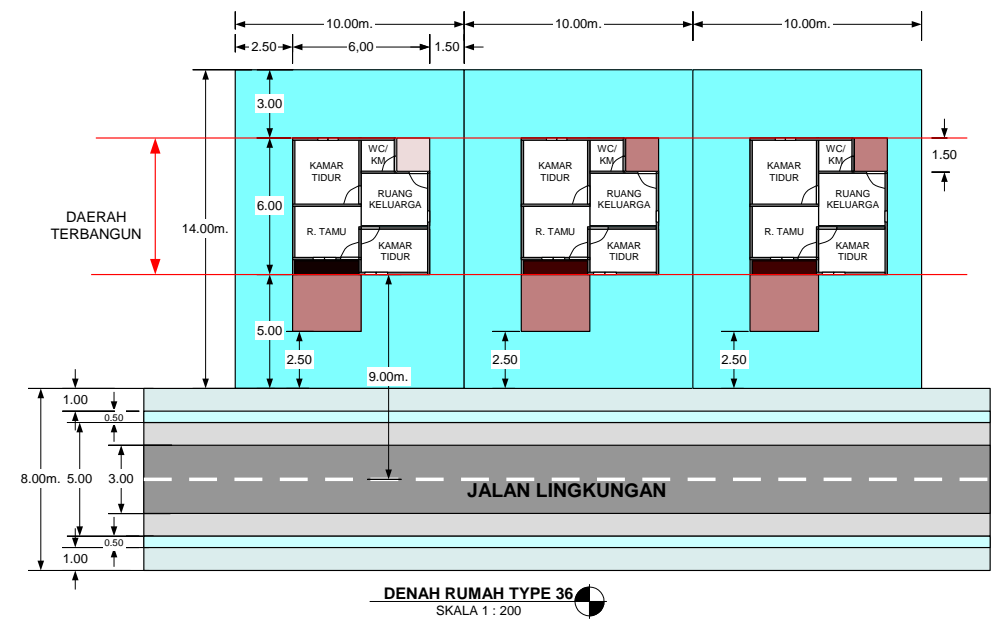




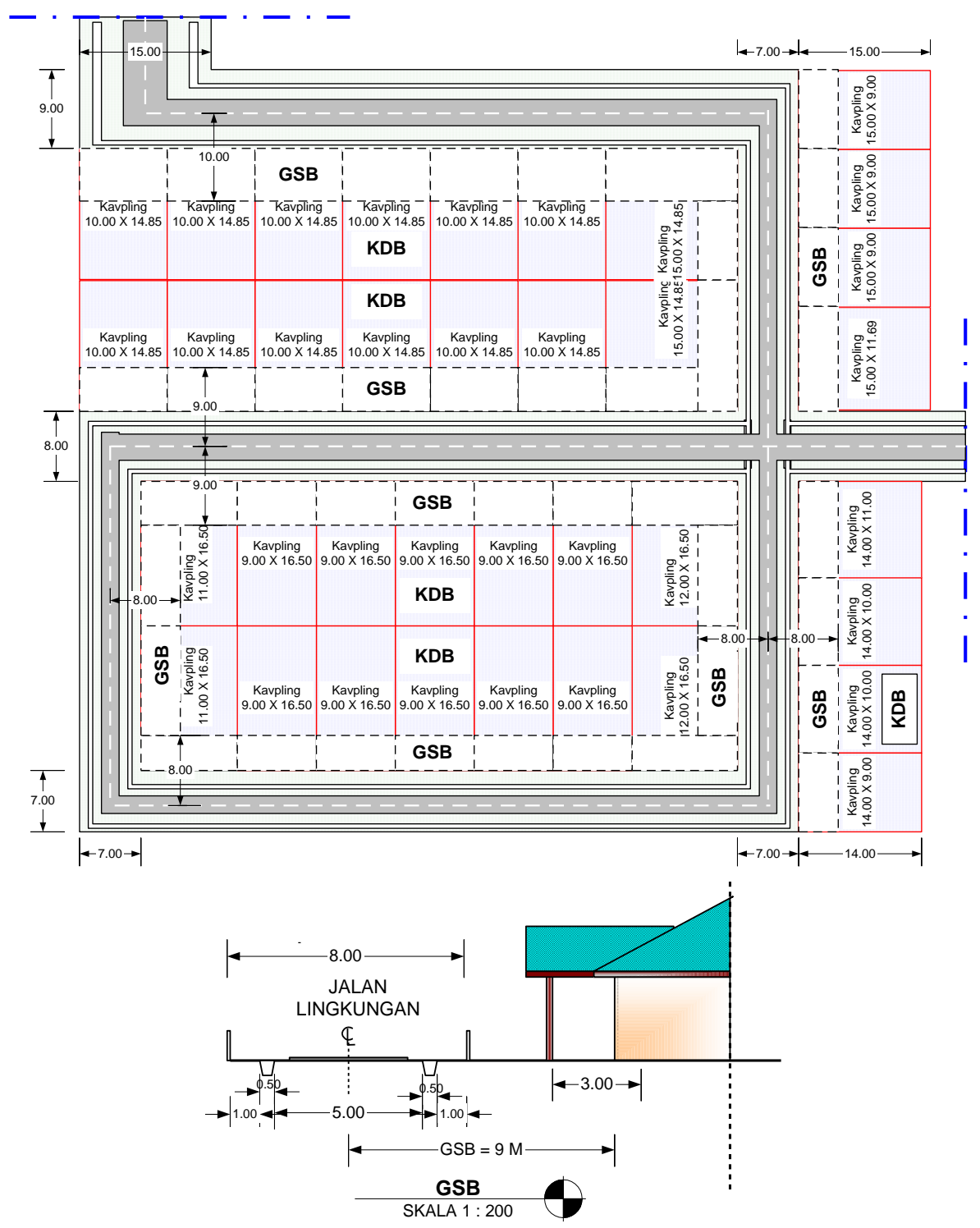

\section{HASIL PEMBAHASAN}

Tabel 4. Hasil Pembahasan Penataan Sistem Infrastruktur

\begin{tabular}{|c|c|c|c|c|}
\hline No. & $\begin{array}{c}\text { Jenis } \\
\text { Infrastruktur }\end{array}$ & $\begin{array}{c}\text { Prasarana Infrastruktur } \\
\text { yang ada }\end{array}$ & $\begin{array}{c}\text { Prasarana Infrastruktur } \\
\text { yang dibuat }\end{array}$ & $\begin{array}{l}\text { Alternatif system Penataan } \\
\text { Infrastruktur yang baru }\end{array}$ \\
\hline 1. & Lingkungan & Tersedia & Tersedia & Tersedia \\
\hline 2. & Lokasi & Sesuai tata guna lahan & Sesuai tata guna lahan & Sesuai tata guna lahan \\
\hline 3. & Prasarana Jalan & $\begin{array}{l}\text { 1.Tidak tersedia Jalan } \\
\text { Poros yang memadai } \\
\text { 2.Jalan Lingkungan } \\
\text { tidak salin } \\
\text { berhubungan }\end{array}$ & $\begin{array}{l}\text { 1.Perlu pembuatan jalan } \\
\text { poros penghubung ke } \\
\text { jalan utama (Jl. G. } \\
\text { Obos dan Yos } \\
\text { Sudarso) } \\
\text { 2.Pembuatan jalan poros } \\
\text { baru untuk akses } \\
\text { keluar masuk kawasan } \\
\text { lebar perkerasan } \geq 6 \mathrm{~m} \\
\text { 3.Penambahan jalan } \\
\text { lingkungan agar jalan }\end{array}$ & $\begin{array}{l}\text { 1.Lebar jalan (DMJ) dibuat } \\
\text { Patok Batas yang jelas } \\
\text { dengan lahan perumahan } \\
\text { 2.Jalan lingkungan } \geq 6 \mathrm{~m} \\
\text { terintegrasi saling } \\
\text { berhubungan (tdk buntu) } \\
\text { 3.Lahan Trase Jalan di } \\
\text { lakukan serah terima pada } \\
\text { saat pemasangan patok dari } \\
\text { pengembang ke Pemkot. }\end{array}$ \\
\hline
\end{tabular}


Alternatif Sistem Penataan Infrastruktur ..., Muhing L. Agau ${ }^{(1)}$, Rusdi H.A. ${ }^{(2)}$, Candra Yuliana ${ }^{(3)}$

\begin{tabular}{|c|c|c|c|c|}
\hline No. & $\begin{array}{c}\text { Jenis } \\
\text { Infrastruktur }\end{array}$ & $\begin{array}{c}\text { Prasarana Infrastruktur } \\
\text { yang ada }\end{array}$ & $\begin{array}{c}\text { Prasarana Infrastruktur } \\
\text { yang dibuat }\end{array}$ & $\begin{array}{l}\text { Alternatif system Penataan } \\
\text { Infrastruktur yang baru }\end{array}$ \\
\hline & & & $\begin{array}{l}\text { lingkungan yang ada } \\
\text { tidak buntu }\end{array}$ & \\
\hline 4. & $\begin{array}{l}\text { Perairan dan } \\
\text { drainase }\end{array}$ & $\begin{array}{l}\text { Saluran terbuka dinding } \\
\text { tanah }\end{array}$ & $\begin{array}{l}\text { 1.Lebar atas dan tinggi } \\
\text { saluran } \geq 10 \% \text { dari } \\
\text { lebar perkerasan jalan. } \\
\text { 2.Pembuatan saluran } \\
\text { dengan dinding batu } \\
\text { belah/batu kali } \\
\text { 3.Saluran pada daerah } \\
\text { yang volume lalu } \\
\text { lintas tinggi dibuat } \\
\text { saluran tertutup. }\end{array}$ & $\begin{array}{l}\text { 1.Lebar atas saluran } \geq 10 \% \\
\text { dari RUMIJA. } \\
\text { 2.Penyiapan lahan untuk } \\
\text { saluran leading (air bersih) } \\
\text { 3.Penyediaan lahan untuk } \\
\text { pengembangan ke drainase } \\
\text { kota. } \\
\text { 4. Batas antar lahan dibuat } \\
\text { saluran batas } \geq 20 \mathrm{~cm} \text { lebar } \\
\text { atas dan tinggi } 20 \mathrm{~cm}\end{array}$ \\
\hline 5. & Fasilitas sosial & $\begin{array}{l}\text { Tidak ada jalan sebagai } \\
\text { jalur hijau di sepanjang } \\
\text { Jalan }\end{array}$ & $\begin{array}{ll}\text { 1.Peningkatan ruang } \\
\text { publik sebagai ruang } \\
\text { hijau pada kiri kanan } \\
\text { jalan pada lahan bahu } \\
\text { jalan } \\
\text { 2. Mengakses ruang } \\
\text { terbuka romum } \\
\text { terdekat yang menjadi } \\
\text { fasilitas kota. }\end{array}$ & $\begin{array}{l}\text { 1.Penyiapan lahan/ Batas } \\
\text { lahan dengan lahan } \\
\text { perumahan sebagai jalur } \\
\text { hijau sepanjang jalan } \\
\text { 2.Penyiapan lahan fasilitas } \\
\text { umum dan ruang public } \\
\text { yang memadai pada } \\
\text { kawasan pemukiman } \\
\text { sebagai asset daerah. }\end{array}$ \\
\hline 6. & $\begin{array}{l}\text { Teknis } \\
\text { Bangunan }\end{array}$ & $\begin{array}{l}\text { 1. Tidak teraturnya GSB } \\
\text { 2.Hilangnya Ruang } \\
\text { terbuka } \quad \text { sebagai } \\
\text { resapan } \\
\text { 3.Melebarnya KDB }\end{array}$ & $\begin{array}{l}\text { 1.Untuk pengembangan/ } \\
\text { renovasi di arahkan ke } \\
\text { bangunan vertical } \\
\text { 2.Mengembalikan } \\
\text { efektifitas KDB yang } \\
\text { dianjurkan } \\
\text { 3.Membuat tempat } \\
\text { tempat ruang terbuka } \\
\text { hijau sebagai ruang } \\
\text { resapan pada lahan } \\
\text { pekarangan }\end{array}$ & $\begin{array}{l}\text { 1. Batas GSB dimulai dari } \\
\text { bangunan terdepan } \\
\text { 2.Jarak GSB } \geq 1,5 \text { x DMJ } \\
\text { diukur dari AS Jalan } \\
\text { 3.KLB 30\%:70\% dari luas } \\
\text { lahan untuk RSS tipe } 21 \text { dan } \\
\text { RS tipe } 36 \text { dengan KDB } \\
60 \%: 40 \% \\
\text { 4. Ruang terbuka sebagai } \\
\text { resapan pada lahan } \\
\text { perumahan } 40 \% \text { dari luas } \\
\text { lahan }\end{array}$ \\
\hline 7. & $\begin{array}{l}\text { Prasarana } \\
\text { Limbah (cair } \\
\text { dan padat) }\end{array}$ & $\begin{array}{l}\text { Tidak tersedia lahan } \\
\text { untuk prasarana limbah } \\
\text { secara tersistem }\end{array}$ & $\begin{array}{l}\text { 1.Pembuatan pewadahan } \\
\text { TPS, } 2 \text { rumah 1 TPS } \\
\text { 2.Pembuatan Septictank } \\
\geq 1 \% \text { dari KLB } \\
\text { 3.Pembuatan saluran } \\
\text { kombinasi pada sisi } \\
\text { kiri dan kanan sebagai } \\
\text { saluran limbah dan } \\
\text { drainase air } \\
\text { permukaan }\end{array}$ & $\begin{array}{l}\text { 1.Disiapkan lahan tempat } \\
\text { prasarana limbah padat } \\
\text { untuk TPS } 2 \text { rumah } 1 \text { TPS } \\
\text { 2. Saluran Batas lahan lebar } \\
\text { atas > } 30 \mathrm{~cm} \text {. Disiapkan } \\
\text { lahan untuk limbah cair. } \\
\text { 3.Pembuatan septictank }>1 \% \\
\text { dari KLB pada masing- } \\
\text { masing rumah. }\end{array}$ \\
\hline
\end{tabular}

Sumber : Hasil Rangkuman Analisis Data dan Pembahasan 


\section{PENUTUP}

\section{Kesimpulan}

Berdasarkan hasil analisis dan pembahasan, maka kesimpulan penelitian adalah sebagai berikut:

1. Perumahan Palangka Permai telah berkembang menjadi kawasan permukiman, akibat terlambat mengantisipasi perubahan berdampak pada penurunan kualitas lingkungan dan terkesan kumuh sehingga mempengaruhi infrastruktur di kawasan tersebut seperti:

a. Prasarana Jalan tidak ada jalan poros yang menghubungkan ke jalan utama.

b. Prasarana drainase, kondisinya tidak layak, karena tidak dapat mengalir secara gravitasi/ tersistem menuju saluran drainase jalan utama.

c. Fasilitas sosial, berkurangnya ruang terbuka hijau sebagai akses publik dan berkurangnya Ruang Milik Jalan (RUMIJA) sebagai jalur hijau.

d. Teknis Bangunan Rumah di kawasan palangka permai sudah berubah bentuk dan tidak sesuai dengan KDB dan GSB.

e. Prasarana Limbah tidak adanya lahan resmi untuk prasarana limbah secara tersistem untuk menampung limbah baik cair maupun padat.

2. Faktor penyebab terjadinya kekumuhan di kawasan pemukiman Palangka Permai adalah karena luas lahan yang disiapkan oleh pengembang perumahan (developer) mengambil standar minimal untuk tipe rumah RSS, tidak tersedianya lahan untuk pengembangan/ renovasi serta tidak ada pengawasan secara teknis bagi pemilik untuk merenovasi dan gambar arsitektur yang disiapkan sebagai standar untuk perubahan KLB, yang akhirnya berdampak pada prasarana pendukung lainnya.

3. Berdasarkan hasil penelitian dan pembahasan maka alternative system penataan infrastruktur adalah sebagai berikut:

a. Prasarana Jalan dengan mengoptimalkan jalan lingkungan menjadi jalan poros, membuat jalan poros baru dengan lebar perkerasan $\geq 6 \mathrm{~m}$, penyediaan jalan lingkungan yang saling berhubungan.

b. Prasarana perairan dan drainase dengan melakukan pengadaan drainase baru, melakukan rehabilitasi terhadap drainase yang sudah ada dengan ukuran lebar atas dan tinggi saluran $\geq 10 \%$ dari lebar perkerasan jalan.

c. Prasarana fasilitas sosial adalah dengan mmengoptimalkan ruang terbuka umum, ruang terbuka pribadi, system ruang terbuka privat, system pepohonan dan tata hijau, bentang alam, pada area jalur hijau.

d. Teknis Bangunan melakukan pengawasan serta tindakan terhadap perubahan tampilan bangunan, dengan mengevaluasi kepemilikan IMB serta membuat peraturan khusus untuk mengatur fungsi bangunan.

e. Prasarana Limbah (cair maupun padat) perlu membentuk organisasi untuk penanganan limbah padat (sampah). Sedangkan untuk penangan limbah cair dengan system pembuangan air limbah setempat (on site system) dengan system cubluk atau septictank dan pembuangan air limbah terpusat (off site system) dengan membuat saluran tertutup kombinasi untuk air limbah dan air permukaan yang mengarah ke lokasi penampungan air limbah terdekat.

\section{DAFTAR PUSTAKA}

Budiani, Ni P. et al. 2004. Infrastruktur Sanitasi Permukiman Kumuh di Denpasar, Laporan Penelitian, Denpasar: Jurusan Arsitektur Fakultas Teknik Univ. Udayana

Catur Sugiyanto dan Bakti Setiawan, 2007. Kajian Aspek Kemasyrakatan di dalam Pengembangan Infrastruktur di Indonesia, Bandung: ITB

Diputra, I G, P. et al. 2004. Permukiman Kumuh di Denpasar: Ditinjau dari Aspek Ruang/Spesial. Laporan Penelitian, Denpasar: Jurusan Arsitektur Fakultas Teknik Univ. Udayana

Jayadinata, Johara, T, 1999, Tata Guna Tanah Dalam Perencanaan Pedesaan Perkotaan dan Wilayah, Penerbit ITB Bandung.

Kodoatie, Robert, J, 2005, Manajemen Infrastruktur, Yogyakarta: Pustaka Pelajar.

Keputusan Menteri Perumahan Rakyat No.4/KPTS/BKP4/1995, tentang Klasifikasi Rumah Tidak Bersusun.

Kuswartojo, Tjuk, 2005, Perumahan dan Permukiman di Indonesia; Upaya membuat Perkembangan kehidupan yang berkelanjutan, Bandung: Penerbit ITB.

Madesyawati, D. et al.2004, Analisis Rumah Kumuh Sebagai Tempat Produksi, Laporan 
Alternatif Sistem Penataan Infrastruktur ..., Muhing L. Agau ${ }^{(1)}$, Rusdi H.A. $^{(2)}$, Candra Yuliana ${ }^{(3)}$

Penelitian. Denpasar: Jurusan Arsitektur

Fakultas Teknik Univ. Udayana

Peraturan Menteri Pekerjaan Umum

No.06/Prt/M/2007 Tentang Pedoman Umum

Rencana Tata Bangunan dan Lingkungan.

Peraturan Menteri Pekerjaan Umum

No.54/PRT/1991 Tentang Pedoman Teknis

Pembangunan Perumahan Sangat

Sederhana.

Prasetyo, D. et al.2004, Pemukiman Kumuh di Denpasar: Ditinjau dari Aspek Sosial Budaya, Laporan Penelitian. Denpasar: Jurusan Arsitektur Fakultas Teknik Univ. Udayana

Rahmayanie, A.A. et al.2004, Aspek Finansial/Sosial Ekonomi Penduduk Permukiman Kumuh, Laporan Penelitian. Denpasar: Jurusan Arsitektur Fakultas Teknik Univ. Udayana

Reksohadiprodjo, 2001, Dimensi Lingkungan Perencanaan Pembangunan, Yogyakarta: Penerbit Gadjah Mada University Press.

Sastra M, Suparno dan Endy Marlina, 2006, Perencanaan dan Pengembangan Perumahan. Yogyakarta: Penerbit Andi.

Sujarto, Djoko, 1994, Proses Perkembangan dan Perencanaan Kota, Departemen Planologi FTSP, ITB, Bandung.

Undang-Undang Republik Indonesia Nomor 4 Tahun 1992 Tentang Perumahan dan Permukiman,

Undang-Undang Nomor 16 Tahun 1992 Tentang Rumah Susun.

Z,R, Langi, A, Wismadi, A， dkk, 2006 Pengembangan dan Manajemen Infrasruktur Indonesia yang Berkeadilan, UI, UGM, ITB. 